\title{
The Womack, Gilbert, and Pearson Sites: Early Eighteenth Century Tunican Entrepots in Northeast Texas
}

Frank Schambach

Arkansas Archaeological Survey

Follow this and additional works at: https://scholarworks.sfasu.edu/ita

Part of the American Material Culture Commons, Archaeological Anthropology Commons, Environmental Studies Commons, Other American Studies Commons, Other Arts and Humanities Commons, Other History of Art, Architecture, and Archaeology Commons, and the United States History Commons

Tell us how this article helped you.

This Article is brought to you for free and open access by the Center for Regional Heritage Research at SFA ScholarWorks. It has been accepted for inclusion in Index of Texas Archaeology: Open Access Gray Literature from the Lone Star State by an authorized editor of SFA ScholarWorks. For more information, please contact cdsscholarworks@sfasu.edu. 


\section{The Womack, Gilbert, and Pearson Sites: Early Eighteenth Century Tunican Entrepots in Northeast Texas}

\section{Creative Commons License}

\section{(c) (1) (8)}

This work is licensed under a Creative Commons Attribution-NonCommercial 4.0 International License 


\title{
THE WOMACK, GILBERT, AND PEARSON SITES: EARLY EIGHTEENTH CENTURY TUNICAN ENTREPOTS IN NORTHEAST TEXAS? ${ }^{1}$
}

\author{
Frank Schambach, \\ Arkansas Archeological Survey
}

For the past few months, I have been working on a detailed response to a paper by James Bruseth, Diane Wilson, and Timothy Perttula (1995) published in the fall issue of Plains Anthropologist. There, these authors challenge my Sanders entrepot hypothesis (Schambach 1995) and my new paradigm for the Mississippi period archeology of the Arkansas Valley (Schambach 1993), claiming that the Sanders focus, as propounded by Alex D. Krieger (1946), is alive and well, so much so that they have renamed it the Sanders phase to ready it for service in the 1990 s and beyond.

As I was finishing my response to that paper, with the intention of summarizing it at this conference, some exciting new evidence emerged which caused me to change my plans. This evidence, I think, settles the argument about the Sanders site because it proves that the people buried in the 21 graves at Sanders were, as I have been arguing on both archeological and bioanthropological grounds, an intrusive population from the Arkansas Valley. It also supports my hypothesis that the Mississippi period population of the Arkansas Valley was significantly different, culturally and biologically, from the Caddo populations south of the Ouachita Mountains.

Perhaps the best way to present this new information is to cite the short section titled "The Bioanthropology of the Skeletons from the Sanders Site" that appears in my response (soon to be published) to Bruseth, Wilson, and Perttula's challenge:

I must begin by clarifying an important point that Bruseth et al. (1995:225) have obfuscated. I am not the one who "argues that the skeletal sample from [the Sanders] site is markedly different from Caddoan populations down the Red River". I'm not qualified to made that kind of argument. I merely pointed out (Schambach 1993: 204-205; Schambach 1995:10-11) that the bioanthropologists have recently begun to notice and puzzle over peculiarities in this group of skeletons compared to those from historically and archeologically documented Caddo sites farther east in the Red River Valley that are inexplicable in terms of Krieger's Sanders focus hypothesis. The first was Dow (1987) who 
observed that the Sanders skeletons differ significantly from the Hatchel-Mitchell skeletons and offered the ad hoc explanation that this was because people at Sanders were intermarrying with Plains people. Then Burnett (1990:393-399), analyzing unpublished data assembled by Jackson, observed that the infection rate in the Sanders skeletons was "dramatically high" compared to other populations in the Red River Valley, an observation that Wilson (personal communication, February 1996) now considers valid. And it was Burnett, not I, who concluded that the Sanders skeletons are "markedly different" overall from Caddo skeletal populations from sites east of Sanders in the Red River Valley. Then Wilson (1993:11) added to the growing list of differences the observation that the Sanders skeletons evince an unusually high degree of degenerative joint disease of a type indicating to her that the Sanders people may have regularly carried heavy loads on their backs or heads and might have done "a great deal of travel[ing]" on foot.

My contribution to this process has been to assemble these observations and note that they raise the same question about the Sanders skeletons that I raise about the artifacts found with them. If they are Caddo, as the conventional wisdom would have it, why are they different in these ways?

And I have pointed out how these differences, inexplicable in terms of Krieger's hypothesis, make sense in terms of mine. A group of traders from the Arkansas Valley would have been genetically different in ways detectable osteologically from people in the Red River Valley (Barnes and Rose 1990:12; Schambach 1993:190-193). Their skeletons could be expected to show, as some of the Sanders skeletons do, evidence of infections with the diseases of childhood that happen to be grimly characteristic of the Mississippi period population of the Arkansas Valley (Brues 1958, 1959; Brown 1984:259; Burnett 1988:212-214), but not of the Red River Valley. And the skeletons of long-distance traders regularly plying the 150 mile riverine and overland route between Spiro and Sanders could be expected to show the kinds of stress induced degeneration that Wilson has identified in the Sanders site skeletons.

I also predicted (Schambach 1993:203) that as these bioanthropological studies progressed, conclusive osteological evidence that the Sanders site skeletons 
represent an Arkansas Valley population might emerge. As luck would have it, such evidence has recently been presented to me by none other than Diane Wilson, one of the coauthors of the "Bruseth et al." attack on my Sanders entrepot hypothesis. I will conclude this section with a brief review of Wilson's new data and a short discussion of their implications for my hypothesis.

Wilson's data (discussed here with her permission) are in a paper prepared for presentation at the 61st Annual Meeting of the Society for American Archaeology (Derrick and Wilson 1995; Wilson and Derrick 1996) on styles of "cranial modeling", i.e., head deformation, exhibited by all skulls from presumed "Caddo" contexts in east Texas. Derrick and Wilson's crucial discovery was that two distinct styles of cranial modeling, produced by different techniques, were in use in the Red River Valley. There is a "tabular" style (Figure 1) which was obviously the norm for the Caddo throughout east Texas and (as Wilson has informed me) southwest Arkansas, since (except one specimen from a site in the Neches drainage) it is the only one represented at all but two sites, Sanders and the nearby Womack site. At these sites, a readily distinguishable "annular" style prevails. My response to that information was a December 7, 1995 letter to Wilson containing the following paragraphs:

"Do you agree that the 'circular' deformation apparently 'produced by a circular binding from the frontal region to the occiput' that Brues describes as 'almost universal' in the Horton population, and which -she notes -- was 'similar to that observed at the Nagle site, which was equated with the type described by Stewart from the Sanders site in Texas' is what you and Sharon Derrick are describing?"

"If so, it seems to me that the limited Red River Valley distribution of this type of cranial modeling supports my hypothesis that the Sanders people were Spiroans from the Arkansas Valley."

Wilson's reply, upon reviewing the papers by Brues $(1957,1958$, 1959) and Stewart (1941), was in the affirmative. Therefore I consider the "Sanders site problem" solved. Wilson and Derrick have, I think, supplied conclusive evidence that most of the people represented by the 


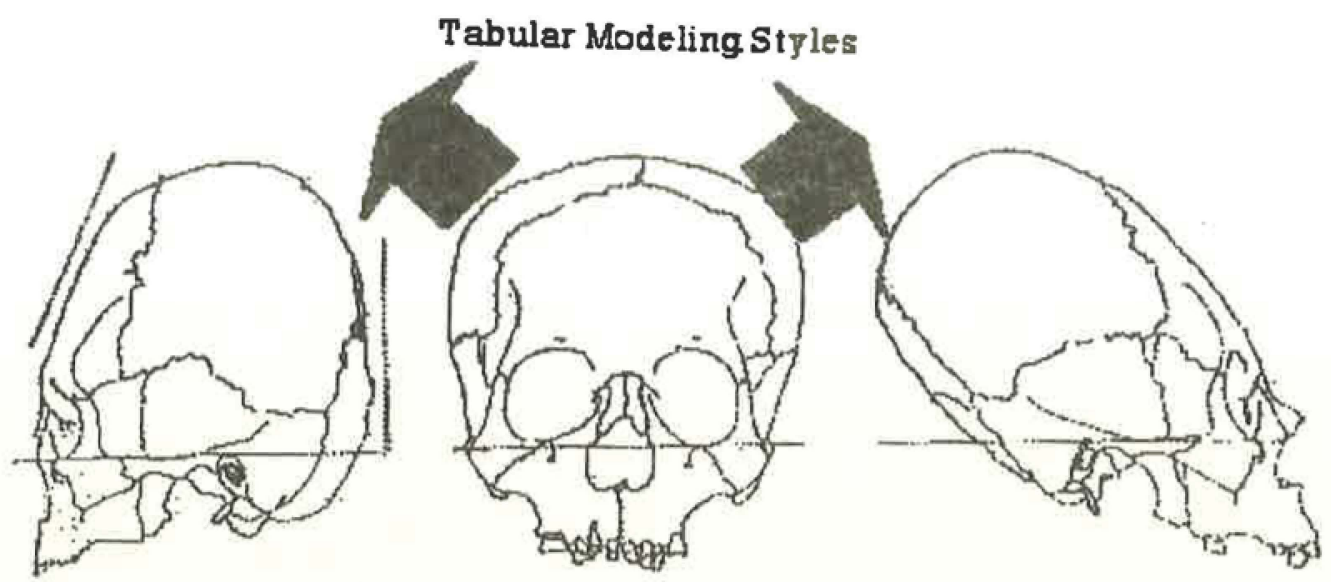

FRONTO-

VERTICO-OCCIPITHL

PARALLZ1,O-FRONTO-OCCIPITAL.

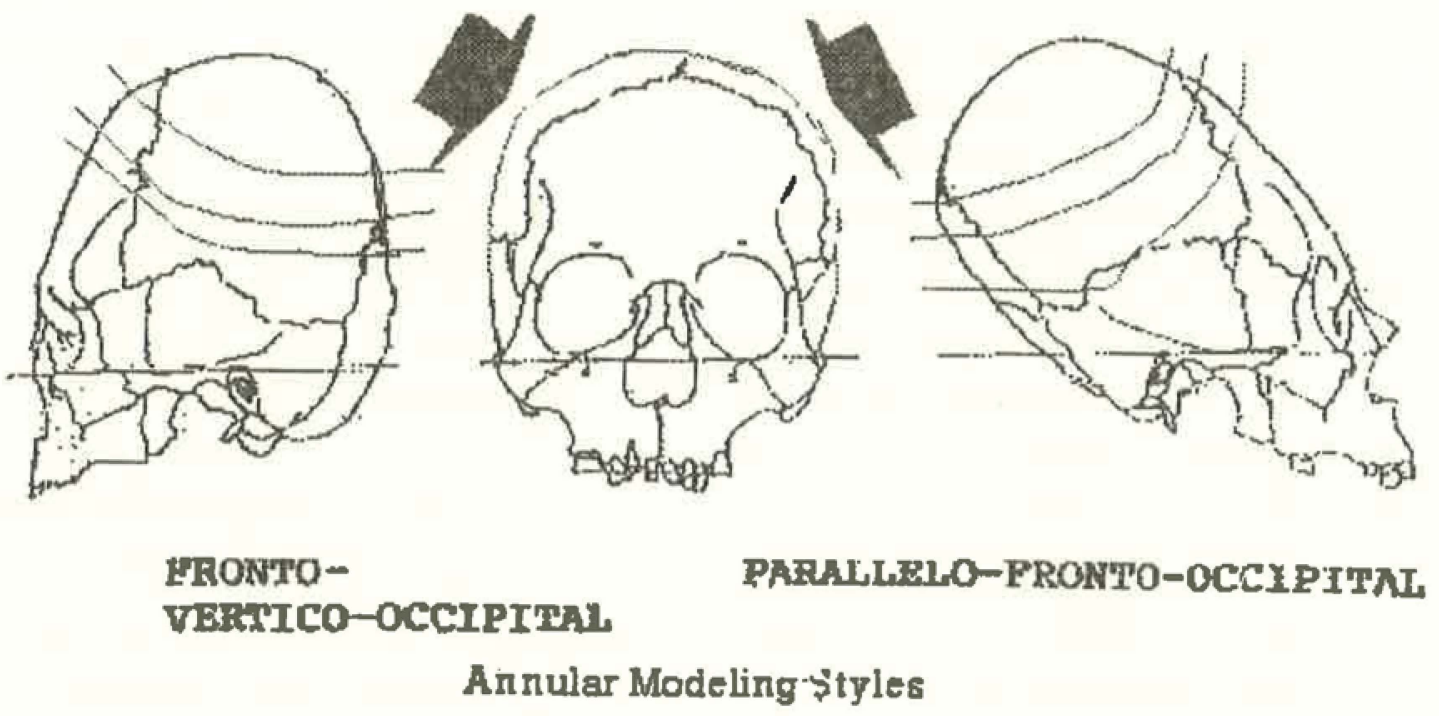

Figure 1. Tabular and Annular Styles of Cranial Modeling (after Wilson and Derrick 1996). 
skeletons from the graves at Sanders were from the Arkansas Valley, just as most of the goods buried with them are from the Arkansas Valley. The Sanders site is a textbook example of a site unit intrusion. My Sanders entrepot hypothesis explains this intrusion.

But who were these Arkansas Valley people known archeologically as the Spiroans? Was anyone in the Southeast practicing annular cranial modeling in historic times? So far, I have been able to find only one reference to this practice, the following passage from Garcilaso's account of the de Soto entrada (Varner and Varner 1951:457458):

The people in this province of Tula differ from all those our Spaniards encountered previously; for, as we have said, the others are fine and handsome, whereas these, both male and female, have loathsome countenances. Even though naturally well featured, they render themselves hideous with devices wrought upon their persons. Their heads are incredibly long and taper off towards the top having been made this way by artifice; for from the moment they are born their heads are bound and are left thus until they are from nine to ten years of age.

This is a perfect description of the annular style of cranial modeling, which makes the head look very long, seen from the front or the side, and makes it "taper off towards the top" when seen from the front (Figure 1). Parallelofronto-occipital flattening also causes the head to look long from the front or side, but it does not cause it to taper above the ears. It causes it to bulge above the ears, to look hyperbrachycephalic, because of the pressure applied from the front and the back.

Garcilaso also gives a plausible description of how annular deformation was accomplished. Instead of binding the infant to a cradle board every night for the first two years or so of life, as seems to have been the custom almost universally in the Southeast (Swanton 1946:539 ff.), the people of Tula simply wrapped their children's heads with broad bands of cloth or leather which they wore more or less constantly until they were eight or nine. The Spaniards must have seen this for themselves because, as is evident from Garcilaso's account, they couldn't communicate with the people of Tula very well, even through interpreters.

Since there is now little doubt that Tula was in the Arkansas Valley, somewhere in the Fort Smith/Spiro area (Early 1993:74-75; Hudson 1993:146-147), Garcilaso's observation fits the bioarcheological data perfectly. As far as I have been able to discover, the Arkansas Valley in eastern Oklahoma is the one place on their route throughout the Southeast where the Spaniards could have seen the annular style of cranial 
modification. It seems to have been characteristic of and unique to this particular Arkansas Valley population from at least A.D. 1100 on (Brues 1957, 1958, 1959). So I think Garcilaso was accurate on this point, despite his generally poor reputation as a historian.

If Garsilaso was describing annular cranial modeling, the implications are very interesting. Most importantly, it would mean that the people of Tula, whom Early (1993:73) equates with the Fort Coffee phase, were probably one and the same with the people of the Spiro phase, which ended in that area about 100 years earlier. I have already pointed out that this was probably the case, because the Spiro phase in the Arkansas Valley differs from the Fort Coffee phase only in nuances in the ceramic assemblage (Schambach 1993:231; Rohrbaugh 1984:279-281). Thus, Garcilaso's description reinforces archeological data which indicate that the Spiroans were still in the Spiro locality 100 years or so after the apparent collapse of Spiro. Furthermore, it indicates that neither the Spiroans nor their Fort Coffee phase descendants were the Wichita who, on solid archeological and historical data (Bell 1984a:309, 323; Brooks 1989:78; Stewart 1941:349; Owsley 1989:133), did not practice "cranial modeling" of any style. Nor, I would say, on massive and -- as we see here -- steadily accumulating archeological and bioanthropological evidence (Schambach 1993:190-193), were they related culturally or biologically to the Caddo south of the

\section{Ouachitas}

It is also clear from the accounts of Garcilaso and the other chroniclers of the de Soto entrada that these Tula, heirs to the Spiroan tradition, a tradition of longdistance trading in my view (Schambach 1993:196-208; 1995), were still importing buffalo products from central Oklahoma in 1542, and, probably, still trading them to people in the Mississippi Valley. Garcilaso reports that "In the town .... our men found serving as bed covers a great number of cowhides which had been softened and dressed without removing the hair; and there were in addition many others waiting to be dressed. Moreover there was beef; but no cows were to be seen in the fields, and it could never be learned from whence the hides had been brought" (Varner and Varner 1951:457). They had been brought, I would say, from the same place the Spiroans obtained buffalo products several centuries earlier, the old Spiroan entrepot near Oklahoma City, 170 miles west of Spiro (Schambach 1993:207-208; 1995:19-20, n.31). And I would bet that some of the hides and "beef" the Spaniards saw at Tula were on the way down the Arkansas to northeastern Arkansas where the Spaniards saw various buffalo products, all probably imported from the Plains by the people of Tula (Quinn 1979:130, $133,180,184)$.

This "new" bioanthropological and documentary evidence that the Spiroan trade network survived the apparent collapse of Spiro as a "ceremonial 
center" ca. 1450 is supported by independent archeological evidence that organized trade between the Mississippi Valley and the Red River Valley via the Arkansas Valley continued after 1450. The most striking evidence of this postSpiro phase trade is the large population of Mound Place Incised bird-effigy bowls that centers in Miller and Lafayette counties in extreme southwestern Arkansas and in Cherokee, Harrison, Titus, and Red River counties in northeastern Texas. These bowls are not found farther east in Arkansas south of the Arkansas Valley (Suhm and Jelks 1962:47-49). Phillips, Ford, and Griffin (1951:147-148) noted 45 years ago that "some of these are very close to St. Francis forms [i.e., forms common in the St. Francis Basin between Memphis and Forrest City, Arkansas], indicating a northeast to southwest movement". The occurrence of Mound Place Incised bowls in Ft. Coffee phase contexts (Rohrbaugh 1982:476-478) and at Sanders ${ }^{2}$ indicates the route over which they were transported from northeastern Arkansas to northeastern Texas and southwestern Arkansas. The turquoise that occurs in Fort Coffee phase contexts in the Arkansas Valley (Rohrbaugh 1982:547) and is abundant in what appear to be post-Sanders phase contexts at the Sanders site and other nearby sites (Jurney and Young 1995:21-23) is additional evidence of this trade and is indicative of the geographical and cultural areas that were probably involved in it.

Who were these descendants (I would say) of the Spiroans that the Spaniards encountered in 1542 as the Tula and, perhaps, as long distance traders, if they were not -- as they could not have been -- the Wichita or the Caddo? Barring the possibility that the people of Tula vanished following their encounter with de Soto, as did so many people in northeastern Arkansas, that leaves only my hypothesis (Schambach 1993:221224) that they were the Tunica.

Until I read Derrick and Wilson's paper, I considered the proposition that these people were Tunica more of a cultural-historical interpretation than an hypothesis because, short of the possibility of using DNA data, I did not see how it could be tested. But there, I found an observation that raises the possibility that it can be tested against archeological and historical data in a way that could confirm it conclusively. This was the observation that the annular style of cranial modeling appears -- let me remind you -- at two sites in the Red River Valley, Sanders and the nearby Womack site. When I first read that, I tried to discount it, hoping the annularly modeled crania from Womack would prove to be from graves that lacked the early eighteenth century French trade goods characteristic of that site, that they were from earlier, Spiroan, graves like those at the nearby Sanders site. But that hope was dashed when I called Diane Wilson, who assured me that at least three of the annularly modeled crania were from graves with historic burial offerings and Womack Engraved pottery. Therefore I was forced to deal with the 
puzzling fact that some four to five hundred years after the Spiroan entrepot at Sanders was abandoned, the same area was occupied by another group of intruders in the Red River Valley who used essentially the same locally distinct style of annular, as opposed to tabular, cranial modeling as had the Spiroans before them. And as I began to think about this new information and about the dilemma it seemed to pose, I realized that it has fascinating implications.

The current interpretation of the main component at the Womack site is that it represents an A.D. 1700-1730 occupation by an "intrusive" Indian group "tentatively" identified as the Wichita or the Kichai which possessed a wide variety of French and Indian trade goods (Harris et al. 1965:360; Story et al. 1990:346; Perttula 1992:171). But if the annular modeling the Womack skulls exhibit means anything, it means these people were not Wichita of any stripe, neither Arkansas Valley Wichita nor western Red River Valley Kichai, because neither the Wichita nor the Kichai practiced cranial modeling. Nor, as we have seen, can they be Caddo. Nor, and this is the dilemma, can they be traced to the Arkansas Valley, as I have done with the earlier Sanders site population, because the consensus among archeologists working with the Arkansas Valley data is that the Spiro locality was abandoned by about 1620 (Perttula 1992:142, 161; Brown 1996:27; Rogers 1996:68). The Spiroans (or "Tulans") were gone, and no one (except, perhaps, me) knows where. So who were the people with annular rather than frontallyoccipitally "modeled" heads who were living and burying their dead at the Womack site between 1700 and 1730 ?

The archeological evidence indicates that -- dare I even say it? -- they were the Tunica. While that may sound outlandish, I am not the first to notice a connection between Womack and Tunican sites in the Red River mouth area. As Harris et al. (1965:360) pointed out in the original Womack site report, the European trade bead types and some of the gun parts found at Womack indicate "a definite connection between Angola Farm, Fish Hatchery site, the Nassonite Post, and (sic) Womack site". As Harris et al. also noted, Angola Farm is a Tunica site excavated by Ford (1936:129-140) in 1934 and occupied, according to Swanton, from about 1709 until 1729 (Harris et al. 1965:358).

Harris et al. (1965:360) argued that "some of the items common to these sites represent goods distributed by the La Harpe party" but, for three reasons, I think otherwise. For one thing, the dates they assign to the European artifacts indicate that the Womack site could have been in use for about twenty years before La Harpe arrived. Secondly, there is no convincing documentary or archeological evidence that any member of the $\mathrm{La}$ Harpe party visited this site. And, third and most importantly, a significant number of the aboriginal goods from Womack also point down the Red River to Angola Farm and other Tunica sites. Indeed, I think there is enough similarity 
Volume 7, Number 3

between the assemblage from Womack and the assemblage from Angola Farm to support the interpretation that Womack represents a site unit intrusion from Angola Farm and that the graves at Womack are classic Tunica graves.

According to Harris et al. (1965:315), 47 of the 56 bead types found at Womack are also found at the Angola Farm site and their 1700-1729 date for Womack is based primarily on numerous close similarities between gun parts found at Womack and gun parts found at the historically dated Angola Farm site (Harris et al. 1965:327,331,332,335,340, 341,343). The correspondences in aboriginal artifacts are also close: the Natchitoches Engraved var. Natchitoches bowl (Harris et al. 1965:Figure 4B; Schambach and Miller 1984:124, Figure 11-11) from Womack is an import from down the Red River, probably from south of the Arkansas line, since pottery of that type is rare in the Great Bend region. The Tunica were using Natchitoches Engraved var. Natchitoches because it appears in sherd form at Angola Farm (Brain 1988:Figure 137e), but they were probably obtaining it by trade from the Natchitoches area. The aboriginal conch shell beads and pendants from Burial 6 at the Bloodhound Hill site, a Tunica cemetery located a short distance north of the Angola Farm site, with which it appears to be approximately contemporaneous (Brain 1988:Figure 126, 173:Figure 146), resemble the conch shell beads and gorgets from the graves at Womack (Harris et al. 1965:305-306, Figure 7).
The snub-nosed end scrapers that are so abundant at Womack have their counterparts, as Perttula (1992:172-173) notes, at the Tunican Haynes Bluff, Russell, and Bloodhound sites. At Bloodhound, one was found next to the left hand of an adult male in Burial 7 (Brain 1988:398). These scrapers remind me of Father Gravier's observation (Brain 1988:296) that although Tunica men did not hunt "they dress [deer and buffalo skins] the best of all Indians that I have seen". I'll bet they did. As I have said elsewhere (Schambach 1993:198-200), I think they were doing it 500 years earlier, using the same snub-nosed scrapers, at sites like Wybark, Sheffield, Tyler-Rose, and Cookson located on the Arkansas River between the Forks of the Arkansas and Spiro. I'll say more about these scrapers in a few minutes.

Finally, there are the graves at Womack. These, you will recall, cannot be Caddo graves because of the annular cranial modeling. The cranial modeling indicates that they can't be Wichita or Kichai either, as does the general absence of 1) diagnostic Wichita or Kichai traits from the graves and other contexts at Womack, and 2) the absence of independent documentary evidence that either group was living this far south and east prior to 1730 . But these graves are, I suggest, absolutely typical Tunica graves in the sense that they contain precisely the same congeries of European trade goods and non-Tunican aboriginal pottery and other goods from various local and non-local sources that appears in every Tunica grave on record. The 
one distinctive characteristic that all Tunica graves identified so far have in common is that the offerings found in them consist mainly of traded goods. They contain little, if anything, that is obviously Tunica-made, so little that the only way they can be identified as Tunican is that they are found at historically documented Tunica sites, and they contain European and aboriginal goods of the right period. This is not a new observation. James A. Ford (1936: 140) noted 60 years ago with respect to Tunica pottery that the Tunica at Angola Farm had "taken over the pottery of the Caddo and Natchez rather thoroughly".

Therefore I consider the historic component at the Womack site a site-unit intrusion from the historic Tunican Angola Farm site. Furthermore, I suggest that the historic component at the Gilbert site (Jelks 1967), located about sixty miles south of the Womack site on the upper Sabine, also represents a Tunican intrusion, only there the intrusion was from the Trudeau site where the Tunica were living during the time the Gilbert site was occupied. We do not have the benefit of Harris and Blaine's scholarship when it comes to comparing the assemblage from the Gilbert site (dated to approximately 1750 , mainly on the basis of European bead types and various gun parts; Blaine and Harris $1967: 41,47,61,67,71,79,80,81$; Harper et al. 1967:104), with that from the Trudeau site, which is dated historically to 17311764 (Brain 1988:66). However, it is obvious that there are many correspondences. At least 17 of the 58 bead types recognized at Trudeau also appear at Gilbert (Brain 1979:116-131) and, as is apparent from Brain's work (1979:214-216), there are some very specific similarities between the gun parts from Gilbert and the guns from Trudeau. For what it is worth to those who (foolishly, I would say) accept Brain's argument that the pottery he calls Winterville Incised var. Tunica is an infallible marker for a Tunican occupation wherever it is found, there is also the fact that, as I pointed out in 1984 (Schambach and Miller 1984:121122) the "Emory Punctated" pottery reported from Gilbert (Story et al. 1967:135-139, Figure 57g,h,i) appears to be practically identical to the Winterville Incised var. Tunica from Trudeau (Brain 1979:234-237).

There is, of course, just one last piece of evidence that is needed to confirm the rather complex hypothesis I am developing here. The hypothesis is that the Spiroans/Tulans that Garcilaso described on the Arkansas in 1541 were the Tunica, as I have been suggesting for years (Schambach 1993). In 1541 they were, hypothetically, still living near Spiro in the Arkansas Valley and their trade network, by then in place for over 500 years, was still up and running. Hypothetically, they were still moving salt, bows, pottery, bison products, and other kinds of commodities and prestige goods over long distances. This probably continued until about 1650 , when the sudden introduction of Spanish horses from the Southwest, and French guns and other trade goods from the 
Volume 7, Number 3

Mississippi Valley disrupted their ancient system. Horse transport superseded human transport and guns superseded bows for warfare, putting the Tunica out of business as far as the vital western half of their trade network was concerned. So, knowing what was going on everywhere in North America between the Pueblo area and the Mississippi Valley, as I imagine they would have if they were the longdistance traders I think they were, most of them moved from the Spiro locality directly to the Yazoo (as they would move from there to the Red River mouth area about 50 years later) to try to insinuate themselves into the hide trade that English traders based on the southern Atlantic coast were operating in that area. Thus, I hypothesize, when they entered history there on the Yazoo in 1699 (Brain 1988:294) they had not come, anciently, from farther up the Mississippi Valley in the Upper Sunflower region as Brain (1988:266277) conjectures on very poor archeological evidence. They had come, recently and probably directly, from the Fort Smith locality in the Arkansas Valley. Probably because they were trying to cut themselves in on the profits rather than merely supply hides at low cost to the English as Indians were supposed to do, they soon got in trouble on the Yazoo, and moved again to the Red River mouth area and, initially, the Angola Farm site.

I will tell you in a moment why I think they went there and how I think they subsequently amassed the wealth that has come to be called the "Tunica Treasure". But first, there is still the matter of the type of evidence needed to confirm my hypothesis about the central involvement of the Tunica in the prehistoric Spiroan trade network and in the operation of entrepots in east Texas during the early historic period. That evidence is, of course, crania from historically documented Tunica graves exhibiting the annular style of modeling that was characteristic of the Spiroan population of the Arkansas Valley in eastern Oklahoma from A.D. 1100 to 1541 . Unfortunately, that evidence is not available, not necessarily because the Tunica did not practice annular cranial modeling, but because (as far as I know) there are no crania from documented Tunica graves that are sufficiently intact for observations on the presence and style of cranial modeling to be made. All we have at the moment is Father Gravier's observation that the Tunica deformed their children's heads (Brain 1988:295), but no historical or bioanthropological evidence of the style of modeling they used.

So confirmation, or rejection, of my hypothesis that the Spiroans were the Tunica and that the so-called Norteno focus sites in northeastern Texas were actually Tunican entrepots must wait the discovery either of intact skulls from historically documented Tunica graves or of explicit historical documentation of the type of cranial modeling they used. But in the meantime, since there are, as far as I can see, no other equally plausible competing hypotheses, I am 
encouraged to continue to build my case for Tunican entrepots in northeastern Texas on other kinds of evidence.

The final, and crucial, piece of evidence I want to consider here bears on two related questions. How did the Tunica amass the wealth in goods (the "treasure") that Leonard Charrier looted from about a hundred of their graves at the Trudeau site (Brain 1979)? And how might the operation of entrepots in northeastern Texas have been involved in that process?

The consensus on the source of the Tunica treasure seems to be that the Tunica acquired it by functioning as "middlemen" in trade between the French and other tribes. The Tunica are supposed to have profited from this trade by virtue of their strategic location in the Red River mouth area between the French in New Orleans and the Caddo, Wichita, Osage, Quapaw and other tribes living upriver in Louisiana, Mississippi, Arkansas, Texas, and Oklahoma (Brain 1979:280-282; Perttula 1992:201; Kidder $1993: 237)$. The problem with this view is that no one has tried to explain exactly what the Tunica did as "middlemen", other than that they had positioned themselves athwart a bottleneck in the main river route between the French and all of these tribes. But how would this have produced profits for them? Were they collecting tolls or tribute from French or Indian traders moving through their territory?

I doubt that the Tunica's role as "middlemen" was either that limited or that passive. I would suggest that, rather than having, accidentally or otherwise, found a way to profit from an endeavor controlled by the French, as everyone seems to assume, the Tunica were profiting from this "French and Indian trade" because, as had (in my view) been their practice for 500 years with salt, bow wood, and other commodities, they were running it lock, stock, and barrel. I would suggest that they controlled the supply of Indian goods to the French, and of French goods to the Indians by establishing their own entrepots at the sources of valuable Indian commodities, specifically the Womack, Gilbert, and (possibly) Pearson (Duffield and Jelks 1961) sites, and moving goods to and from them themselves.

The goods moving through these entrepots probably included all the important commodities of the eighteenth century French-Indian frontier (Gregory 1973:289): salt, hides, Osage orange bows, European guns and ammunition, other European goods ranging from axes to ornaments, and particularly (I think) horses. Horses, generally considered one of the main sources of Tunica wealth (Gregory 1973:11; Swanton 1911:312; Brain 1979:282), were probably also one of the main reasons, if not the main reason, for Tunican interest in the Womack, Gilbert, and Pearson sites. Indeed, as I will try to demonstrate, they probably account for the locations of these sites as well.

There seems to be no doubt that the 
Tunica were horse traders. The Tunica chief, Cahura-Joligo, was "renowned for his involvement in the horse trade" and a wealthy man by European standards for that time and place because of it (Gregory 1973:11; Swanton 1911:312; Brain 1979:282). Because he was a chief, he probably was not involved in this enterprise alone; the whole tribe would have been involved and profiting from it. The key question about this horse trade, the mechanics of which are unknown, is: where did the Tunica get horses in the period between 1700 and 1760 , the time the "Tunica treasure" was accumulated? Conventional thinking on the horse trade in Louisiana between 1700 and 1760 is that, despite Spanish opposition to trade between the Caddo and the French in Louisiana (particularly if it involved guns and ammunition), horses were filtering into the French territory in the Mississippi Valley from the Spanish settlements in the Southwest via the Hasinai and the Natchitoches (Gregory 1973:281). Some evidently were, but that does not explain the Tunican involvement in the horse trade. Had they managed, somehow, to insinuate themselves between the French and the Hasinai? Nor, there is reason to believe, does it account for all the horses that were coming into Louisiana. By 1720 , according to Wedel (1981:36-37), the Spaniards were making it "more difficult" for the French to get horses "through Hasinai Caddo middlemen", and the French were exploring the possibility of getting them from the Wichita or the Osage. One reason for Bienville's interest in La Harpe's second trip to the Wichita, according to Wedel (1981:37-38) was "the fact that the Tawakoni [Wichita] were reported to have large numbers of horses", although the French did not know where they were getting them.

I think there is good historical and circumstantial evidence that the Tunica, by virtue of their long and continuing familiarity with the Red River Valley in the vicinity of their old entrepot at the Sanders site, and with their old homeland, the Arkansas Valley, knew about the Wichita's horses long before the French heard about them, that they knew the Wichita were getting them from a significant and growing feral herd in northeastern Texas that was unknown to Europeans of that era (and has remained unknown to archeologists and most historians of this one), and that they were involved with the Wichita in the procurement of horses from this herd, some of which they traded to the French in Louisiana.

This hypothesis came to mind when I began thinking about why the Gilbert site, located near the headwaters of the Sabine, should, like Womack sixty miles to the north on the Red River, be loaded with French trade goods. It seems likely that whatever the so-called "Norteno focus" people who frequented the Womack site did to get French trade goods in quantity, those frequenting the Gilbert site a few decades later probably did too. But unlike Womack, which was well situated to command what trade and travel there was up and down the Red River Valley, Gilbert seems to have been 
off the beaten path, an unlikely spot for trade goods to accumulate in quantity. There is, however, one important common element in the locations of these sites: both are precisely on the edge of the Blackland Prairie (Fenneman 1938:102-108, Figure 27, Plate VII), as are the two other northeastern Texas sites with so-called "Norteno focus" components, Sanders and Pearson. Thus the question is: what was attracting people to the edge of the Blackland Prairie between 1700 and 1760? Certainly it was not buffalo hunting, considering the dearth of buffalo bones in the faunal remains from the sites themselves and Lynott's (1980) argument that the grasses of the Blackland Prairie were not attractive to buffalo. But there is historical evidence that the attraction was feral horses.

According to the environmental historian Dan Flores (1985:102 n.8), when Domingo Teran de Los Rios traveled to the Upper Nasoni village on the Red River in northeastern Texas in 1691 with the intention of establishing a mission, he brought "more than 1000 horses and mules ... at least 200 of which were lost". Apparently, some of these animals colonized the Blackland Prairie so successfully that they increased into a large feral herd whose existence remained unknown to Europeans until American "mustangers" discovered it around 1800 . It then became a major source for the feral horses they brought into the southeast. In 1802 alone "an estimated 7300 Texas horses", most of them apparently from the Blackland
Prairie herd, "passed through Louisiana to eastern markets". Despite what must have been heavy pressure from the mustangers, the herd seems to have survived until about 1820 , at least. When the trader Anthony Glass ascended the Sulphur River from Natchitoches in 1808, he began to see feral horses immediately upon entering the Blackland Prairie. Seven days later on Bois d'Arc Creek about "75 miles from its mouth", and from the Sanders and Womack sites, he "saw great numbers of wild horses" (Flores 1985:43-44). When Thomas Nuttall visited the Red River Valley in 1819 , he found the first "native stands" of bois d'arc growing on "the Horseprairie [basically the northern extension of the Blackland Prairie across the Red River], 15 miles above the mouth of the Kiamesha" and directly across the Red River from the Womack and Sanders sites. This prairie, Nuttall (1980:173) explained, "derives its name from the herds of wild horses, which till lately frequented it, and of which we saw a small gang".

Granted that the Blackland Prairie horse herd was of a size to be economically important around 1800 , could it have been an important source of horses for the Wichita and the Tunica about a hundred years earlier? Probably. Between 1691, the time of the Teran expedition, and 1701, the time horses started appearing in Tunica villages in the Red River mouth area, according to Gregory (1971:281), and the time (hypothetically speaking) the Womack entrepot was probably opened by the 
Tunica, the horses lost by the Spaniards could have increased, assuming 50 to 100 animals to start and the exponential growth characteristic of such situations at that time (Crosby 1972:82-84), to 5000 animals or more. By 1719 , the year La Harpe established his post on the Red River and the approximate time that the occupation of the Womack site ended, there could have been as many as 50,000 horses on the Blackland Prairie. By 1750 , the generally agreed upon central date for the occupation of the Gilbert site, this herd could have numbered in the millions, mathematically speaking. Ecologically speaking, it had probably stabilized at the maximum carrying capacity for the Blackland Prairie. Considering the number of square miles involved, and the apparent scarcity of buffalo (Lynott 1980) which would otherwise have competed with the horses for food, their number could have been in the hundreds of thousands.

The Tunica, who -- according to my hypothesis that the Sanders site was a Spiroan entrepot (Schambach 1995) -had been exploiting the trade potential of the Blackland Prairie bois d'arc for 500 years, would have known about this growing horse herd early on. So, I suspect, would the Caddo of the western reaches of the Red River beyond the Great Bend, since they had to go to the Blackland Prairie to get their bow wood. So, by 1719 , might the Osage, since in that year La Harpe (Smith 1958/9:383) met a party of twenty of them coming down the Kiamichi (headed, perhaps, for the Blackland Prairie to get horses and bois d'arc) when he traveled from his newly established "Nassonite Post" on the Red River to the Arkansas Valley. But most importantly, I think, as far as the question of the function of the Womack site is concerned, the Wichita must have known about the Blackland Prairie horse herd. I suspect that it was an important source, if not the main source, for the "large number of horses" (Wedel 1981:37) that the Wichita had, the horses that attracted the attention of the French in New Orleans, ca. 1720. Although the crania with annular modeling from the graves, at Womack indicate that someone other than the Wichita (the Tunica, in my opinion) "owned and operated" the Womack site, there is archeological evidence that Harris et al. (1965:360) were right in associating the Wichita with the Womack site in some way. End scrapers of Kay County, Oklahoma chert, a catlinite pipe fragment (Harris et al. 1965:291-292,294,298) and, less specifically, triangular arrowpoints (Harris et al. 1965:Figure 1b-e) and clay elbow pipes found at Womack (Harris et al. 1965:Figure 6i-j) indicate contact with people in north central Oklahoma. On the other hand, artifacts from the historic Wichita Bryson-Paddock (Hartley and Miller 1977) and Deer Creek (Wedel 1981) sites on the Arkansas River in north central Oklahoma, particularly sherds from Bryson-Paddock of Womack Engraved pottery (Bell 1984b:Figure $17,3 \mathrm{~h}$ ) that must have come from the Red River Valley and European trade beads of the same types found at Angola Farm and Womack (Brain 1979:116- 
131), indicate who the early historic period central Oklahomans visiting the Womack site were.

Thus it would appear that soon after 1700 the Wichita began bringing buffalo hides and other buffalo products, catlinite pipes, and (I imagine) locally procured and halter trained feral horses to the Tunica entrepot at Womack to exchange for the French guns and ammunition they needed to fight their battles with the Apaches and to keep their neighbors to the northeast, the Osage, off their backs. Therefore, I suggest that the Tunica obtained their treasure mostly by exploiting between 1700 and 1760 , in cooperation with the Wichita of north central Oklahoma, a supply of feral Spanish horses on the Blackland Prairie that the Europeans did not know about. Their first entrepot was at Womack, with some occupation of the nearby Sanders site, the site of their original Red River entrepot 500 years earlier. Considering that some of the European trade goods indicate the site could have been occupied as early as 1675 (Harris et al. 1965:360) and considering Gregory's (1973:281) observation that the Tunica were obtaining horses from somewhere up the Red River as early as 1701 , I estimate that the entrepot at Womack had been in operation for about 20 years when La Harpe established the Nassonite Post 110 miles down the Red River from it in 1719. The trade goods at Womack indicate that occupation ended prior to about 1729 (Harris et al. 1965:360), while those from the Gilbert site (Jelks 1967:243), and possibly the nearby Pearson site
(Duffield and Jelks 1961:79), indicate that those occupations began about the time Womack was abandoned. This suggests that the Tunica moved their entrepot south to the headwaters of the Saline soon after La Harpe opened his post in 1719. Their main reason may have been to avoid bringing horses down the Red River past the newly established French post, thus blowing the cover on the Blackland Prairie horse herd. Increasing pressure from the Osage may have been another factor. Or, maybe they just found the Gilbert site more convenient to their home base at the mouth of the Red River.

Considering that snub-nosed endscrapers were probably not butchering tools but tools "used to remove hair and reduce hide thickness, later steps in hide processing" (Creel 1991:42-43), the extraordinarily large numbers of these tools at Womack (872 specimens; Harris et al. 1965:294-295) and Gilbert (418 specimens; Jelks 1967:197-198) leave no doubt in my mind that these were hide trading as well as horse trading entrepots, places where the Tunica received raw hides from the Wichita and prepared them for transport and trade to the east and southeast in Arkansas and Louisiana.

In conclusion, I would say that I agree completely with Gregory (1973:v, 275; Jeter et al. 1989:238-239) that when Europeans began moving into the Lower Mississippi Valley, the Trans-Mississippi South, and the Southern Plains, they didn't have to go to the trouble of finding out for themselves what the re- 
sources of this vast area were and of establishing the complex system of trade relationships with dozens of different tribes that was necessary to obtain them. They simply plugged themselves into "an established Indian trade network", something that was easy for them to do since the Indians welcomed the goods they had to offer. I am convinced that this Indian trade network was, as Gregory says, "a very complex system of barter extending from the Mississippi River to eastern New Mexico ... and from the Arkansas River to the Gulf" and that, as he also says, "Items exchanged included ceramics, salt .... hides, Osage orange (bois d'arc) wood for bows, and horses and
Native American slaves from the Plains and Southwest". All I am doing in reinterpretation of the Spiroan phenomenon, of the Sanders and Nagle sites, and now of Womack, Gilbert, and possibly, Pearson, is marshaling evidence that this was indeed a "system" and that it was the creation of the Tunica. I think that there is good evidence that they (as the Spiroans) established it around A.D. 1000 , that they (as the Tula) were running it when the Spaniards invaded the Mississippi Valley in 1542, and that they were still running it one hundred and sixty years later when the French arrived in Louisiana.

\section{REFERENCES}

Barnes, James E., and Jerome C. Rose 1990 Dental Morphological Variants and Kinship Among Prehistoric Caddo. Paper presented at the 55th Annual Meeting of the Society for American Archeology, Las Vegas.

Bell, Robert E.

1984a The Plains Villagers: The Washita River. In Prehistory of Oklahoma, edited by Robert E. Bell, pp. 307-324. Academic Press, Orlando.

1984b Protohistoric Wichita. In Prehistory of Oklahoma, edited by Robert E. Bell, pp. 363-378. Academic Press, Orlando.
Blaine, Jay C., and R.K. Harris

1967 Guns. In "The Gilbert Site: A Norteno Focus Site in Northeastern Texas", edited by Edward B. Jelks. Bulletin of the Texas Archeological Society 37:33-86.

Brain, Jeffrey $\mathbf{P}$.

1979 Tunica Treasure. Reports of the Peabody Museum of Archaeology and Ethnology Vol. 71. Harvard University, Cambridge.

1988 Tunica Archaeology. papers of the Peabody Museum of Archaeology and Ethnology Vol. 78. Harvard University, Cambridge. 
Brooks, Robert L.

1989 Village Farming Societies. In From Clovis to Comanchero: Archeological Overview of the Southern Great Plains, edited by Joe S. Hays, Douglas W. Owsley, Richard L. Jantz, Murray K. Marks, and Mary H. Manhein, pp. 137-156. Research Series No. 35. Arkansas Archeological Survey, Fayetteville.

Brown, James A.

1984 Arkansas Valley Caddoan: The Spiro Phase. In Prehistory of Oklahoma, edited by Robert E. Bell, pp. 241-263. Academic Press, Orlando.

1996 The Spiro Ceremonial Center: The Archaeology of Arkansas Valley Caddoan Culture in Eastern Oklahoma, Volumes 1 and 2. Memoir No. 29. Museum of Anthropology, University of Michigan, Ann Arbor.

Brues, Alice M.

1957 Skeletal Material from the Nagle Site. Bulletin of the Oklahoma Anthropological Society 5:101106.

1958 Skeletal Material from the Horton Site. Bulletin of the Oklahoma Anthropological Society 6:27-32.

1959 Skeletal Material from the Morris Site, Cd-39. Bulletin of the Oklahoma Anthropological Society 7:63-70.
Bruseth, James E., Diane E. Wilson, and Timothy K. Perttula

1995 The Sanders Site: A Spiroan Entrepot in Texas? Plains Anthropologist 40(153):223-236.

Burnett, Barbara A.

1988 The Biological Synthesis. In Human Adaptation in the Ozark and Ouachita Mountains, edited by George Sabo III, Ann M. Early, Jerome C. Rose, Barbara A. Burnett, Louis Vogel, Jr., and James P. Harcourt, pp. 193-220. Research Series No. 31. Arkansas Archeological Survey, Fayetteville.

1990 The Bioarcheological Synthesis of the Gulf Coastal Plain Study Area. In The Archeology and Bioarcheology of the Gulf Coastal Plain, edited by Dee Ann Story, Janice A. Guy, Barbara A. Burnett, Martha Doty Freeman, Jerome C. Rose, D. Gentry Steele, Ben W. Olive, and Karl J. Reinhard, pp. 385-508. Research Series No. 38. Arkansas Archeological Survey, Fayetteville.

Creel, Darrell

1991 Bison Hides in Late Prehistoric Exchange in the Southern Plains. American Antiquity 56(1):40-49.

Crosby, Alfred W., Jr.

1972 The Columbian Exchange: Biological and Cultural Consequences of 1492. Greenwood Press, Westport, Connecticut. 
Volume 7, Number 3

Derrick, Sharon McCormick, and Diane E. Wilson

1995 Cranial Modeling as an Ethnic Marker Among the Prehistoric Caddo. Unpublished paper cited with permission of the authors.

Dow, Laura Ann Brantly

1987 The Genetic Affinities and Adaptive Success of Three Groups of Late Prehistoric Amerindians from Texas. Unpublished M.A. thesis, Department of Anthropology, The University of Texas, Austin.

Duffield, Lathel F., and Edward B. Jelks 1961 The Pearson Site: A Historic Indian Site at Iron Bridge Reservoir, Rains County, Texas. Anthropology Series No. 4. Department of Anthropology. The University of Texas, Austin.

Early, Ann M.

1993 Finding the Middle Passage: The Spanish Journey from the Swamplands to Caddo Country. In The Hernando de Soto Expedition West of the Mississippi, 1541-1542, edited by Gloria A. Young and Michael P. Hoffman, pp. 68-77. University of Arkansas Press, Fayetteville.

Fenneman, Nevin M.

1938 Physiography of Eastern United States. McGraw-Hill Book Company, New York.
Flores, Dan L. (editor)

1985 Journal of an Indian Trader: Anthony Glass and the Texas Trading Frontier, 1790-1810. Texas A\&M University Press, College Station.

Ford, James A.

1936 Analysis of Indian Village Site Collections from Louisiana and Mississippi. Anthropological Study No. 2. Department of Conservation, Louisiana Geological Survey, New Orleans.

Gregory, Hiram F., Jr.

1973 Eighteenth-Century Caddoan Archaeology: A Study of Models and Interpretation. Ph.D. Dissertation, Department of Anthropology, Southern Methodist University. University Microfilms, Ann Arbor, Michigan.

Harris, R. King, Inus Marie Harris, J.C. Blaine, and Jerrylee Blaine

1965 A Preliminary Archaeological and Documentary Study of the Womack Site, Lamar County, Texas. Bulletin of the Texas Archeological Society 36:287364.

Harper, Loyd, Ruby Harper, R.K. Harris, Inus M. Harris, Edward B. Jelks, and J. Ned Woodall

1967 Ornaments. In "The Gilbert Site: A Norteno Focus Site in Northeast Texas", edited by Edward B. 
Jelks. Bulletin of the Texas Archeological Society 37: 87-104.

Hartley, John D., and A.F. Miller 1977 Archaeological Investigations at the Bryson-Paddock Site: An Early Contact Period Site on the Southern Plains. Archeological Site Report No. 32. Oklahoma River Basin Survey. University of Oklahoma, Office of Research Administration, Norman.

Hudson, Charles

1993 Reconstructing the de Soto Expedition Route West of the Mississippi River: Summary and Contents. In The Hernando de Soto Expedition West of the Mississippi, 1541-1543, edited by Gloria A. Young and Michael P. Hoffman, pp. 143-154. University of Arkansas Press, Fayetteville.

Jelks, Edward B. (editor)

1967 The Gilbert Site: A Norteno Focus Site in Northeast Texas. Bulletin of the Texas Archeological Society 37:1-247.

Jeter, Marvin D., Jerome C. Rose, Ishmael Williams, Jr., and Anna M. Harmon

1989 Archeology and Bioarcheology of the Lower Mississippi Valley and Trans-Mississippi South in Arkansas and Louisiana. Research Series No. 37. Arkansas Archeological Survey, Fayetteville.
Jurney, David H., and William Young 1995 Southwestern Pottery and Turquoise in Northeastern Texas. Caddoan Archeology Newsletter 6(2):15-28.

Kidder, Tristram R.

1993 The Glendora Phase: Protohistoric-Early Historic Culture Dynamics on the Lower Ouachita River. In Archaeology of Eastern North America: Papers in Honor of Stephen Williams, edited by James B. Stoltman. Archaeological Report No. 25. Mississippi Department of Archives and History, Jackson.

Krieger, Alex D.

1946 Culture Complexes and Chronology in Northern Texas, with Extensions of Puebloan Datings to the Mississippi Valley. Publication 4640. The University of Texas, Austin.

Lynott, Mark J.

1980 Prehistoric Bison Populations of Northcentral Texas. Bulletin of the Texas Archeological Society 50:89-101.

Neumann, Geog K.

1942 Types of Artificial Cranial Deformation in the Eastern United States. American Antiquity 3:306-310. 
Volume 7, Number 3

Nuttall, Thomas

1980 A Journal of Travels into the Arkansas Territory During the Year 1819, edited by Savoie Lottinville. University of Oklahoma Press, Norman.

Owsley, Douglas W.

1989 The History of Bioarcheological Research in the Southern Great Plains. In From Clovis to Comanchero: Archeological Overview of the Southern Great Plains, edited by Joe S. Hays, Douglas W. Owsley, Richard L. Jantz, Murray K. Marks, and Mary H. Manhein, pp. 123-136. Research Series No. 35. Arkansas Archeological Survey, Fayetteville.

Perttula, Timothy K.

1992 The Caddo Nation: Archaeological and Ethnohistoric Perspectives. University of Texas Press, Austin.

Phillips, Philip, James A. Ford, and James B. Griffin

1951 Archaeological Survey in the Lower Mississippi Alluvial Valley, 1940-1947. Papers of the Peabody Museum of American Archaeology and Ethnology Vol. 25. Harvard University, Cambridge, Massachusetts.

Quinn, David B.

1979 The Expedition of Hernando de Soto and his Successor, Luis de Moscoso, 1538-1543. In New
American World: A Documentary

History of North America to 1612, Volume 2, edited and commentary by David B. Quinn, pp. 90-198. Arno Press, New York.

Rogers, J. Daniel

1996 Markers of Social Integration: The Development of Centralized Authority in the Spiro Region. In Political Structure and Change in the Prehistoric Southeastern United States, edited by John F. Scarry, pp. 53-68, University Press of Florida, Gainesville.

Rohrbaugh, Charles L.

1982 Spiro and Fort Coffee Phases: Changing Cultural Complexes of the Caddoan Area. PhD. Dissertation, Department of Anthropology, University of WisconsinMadison. University Microfilms, Ann Arbor, Michigan.

1984 Arkansas Valley Caddoan: Fort Coffee and Neosho Foci. In Prehistory of Oklahoma, edited by Robert E. Bell, pp. 265-283. Academic Press, Orlando.

Schambach, Frank F.

1993 Some New Interpretations of Spiroan Culture History. In Archaeology of Eastern North America: Papers in Honor of Stephen Williams, edited by James B. Stoltman, pp. 187-230. Archaeological Report No. 25. 
Mississippi Department of Archives and History, Jackson.

1995 A Probable Spiroan Entrepot in the Red River Valley in Northeast Texas. Caddoan Archeology Newsletter 6(1):1025.

Schambach, Frank F., and John E. Miller 1984 A Description and Analysis of the Ceramics. In Cedar Grove: An Interdisciplinary Investigation of a Late Caddo Farmstead in the Red River Valley, edited by Neal L. Trubowitz, pp. 109-170. Research Series No. 23. Arkansas Archeological Survey, Fayetteville.

Smith, Ralph A.

1958-1959 Account of the Journey of Bénard de la Harpe: Discovery Made by Him of Several Nations Situated in the West. Southwestern Historical Quarterly 62(1-4).

Stewart, T.D.

1941 The Circular Type of Cranial Deformation in the United States. American Journal of Physical Anthropology 28:343-351.

Story, Dee Ann, Janice A. Guy, Barbara A. Burnett, Martha Doty Freeman, Jerome C. Rose, D. Gentry Steele, Ben W. Olive, and Karl J. Reinhard 1990 The Archeology and Bioarcheology of the Gulf Coastal Plain, Volumes 1 and 2.
Research Series 38. Arkansas Archeological Survey, Fayetteville.

Story, Dee Ann, Byron Barber, Estalee Barber, Evelyn Cobb, Herschel Cobb, Robert Coleman, Kathleen Gilmore, R.K. Harris, and Norma Hoffrichter

1967 Indian Artifacts: Pottery Vessels. In "The Gilbert Site: A Norteno Focus Site in Northeast Texas", edited by Edward B. Jelks. Bulletin of the Texas Archeological Society 37:87-104.

Suhm, Dee Ann, and Edward B. Jelks (editors)

1962 Handbook of Texas Archeology: Type Descriptions. Special Publication No. 1, Texas Archeological Society, and Bulletin No. 4, The Texas Memorial Museum, Austin.

Suhm, Dee Ann, Alex D. Krieger, and Edward B. Jelks

1954 An Introductory Handbook of Texas Archaeology. Bulletin of the Texas Archeological and Paleontological Society 25.

Swanton, John R.

1911 Indian Tribes of the Lower Mississippi Valley and Adjacent Coast of the Gulf of Mexico. Bulletin 43. Bureau of American Ethnology, Smithsonian Institution, Washington, D.C.

1946 The Indians of the Southeastern United States. Bulletin 137. 
Bureau of American Ethnology, Smithsonian Institution, Washington, D.C.

Varner, John Grieg, and Jeanette Johnson Varner

1951 The Florida of the Inca. University of Texas Press, Austin.

Wedel, Mildred Mott

1981 The Deer Creek Site, Oklahoma: A Wichita Village Sometimes Called Ferdinandina: An Ethnohistorian's View. Series in Anthropology No. 5. Oklahoma Historical Society, Oklahoma City.
Wilson, Diane E.

1993 Incidence of Degenerative Joint Disease Among the Sanders Site (4ILR2) Population. Paper presented at the 35 th Caddo Conference, Norman, Oklahoma.

Wilson, Diane E., and Sharon McCormick Derrick

1996 Cranial Modeling as an Ethnic Marker Among the Caddo. Paper presented at the 61st Annual Meeting of the Society for American Archaeqlogy, New Orleans.

\section{END NOTES}

1) This is a lightly revised version of the paper I read at the 38th Caddo Conference, Natchitoches, Louisiana, March 29, 1996.

2) In December 1995, I observed one excellent specimen of this type, consisting of most of a single pot in fragments, in the Texas Archeological Research laboratory collections from the midden area at the Sanders site. 